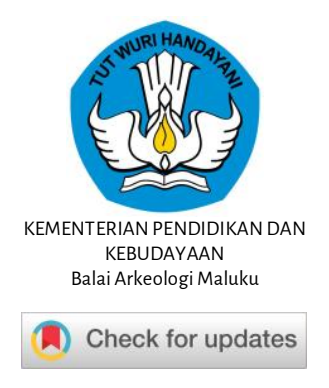

Kapata Arkeologi, 15(1) 2019, 25-34

p-ISSN: 1858-4101, e-ISSN: 2503-0876

KAPATA ARKEOLOGI

SCIENTIFIC JOURNAL OF ARCHAEOLOGY AND CULTURAL STUDIES

Accredited by the Indonesian Ministry of Research, Technology, and Higher Education (RISTEKDIKTI)
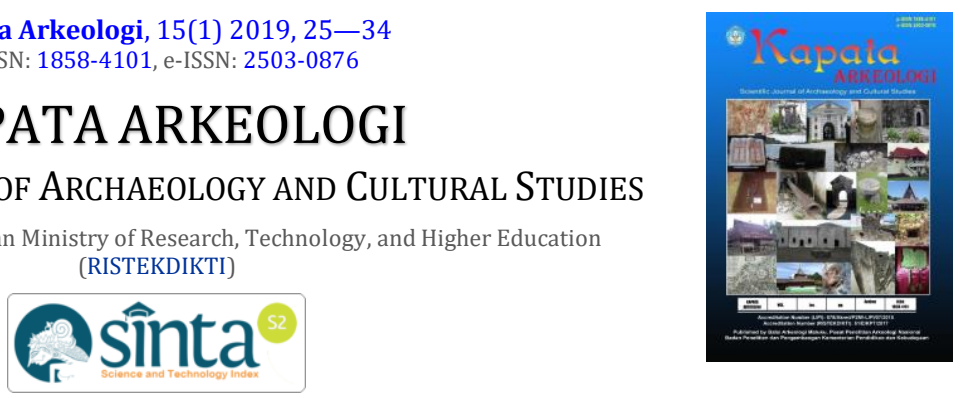

http://kapata-arkeologi.kemdikbud.go.id/

\title{
Preservation OF World Heritage Sites VieWED FROM THE PERSPECTIVE OF SUSTAINABLE TOURISM DEVELOPMENT
}

\author{
Roby Ardiwidjaja \\ Tourism Research and Development Center \\ Kementerian Pariwisata dan Ekonomi Kreatif \\ J1. Medan Merdeka Barat No. 17, Jakarta Pusat 10110, Indonesia \\ r_ardiwidjaja@yahoo.com
}

Received: 02/03/2018; revisions: 25/05 — 02/11/2018; accepted: 01/12/2018

\begin{abstract}
Today, the identity of Indonesian people faces a severe problem due to the influence of globalization, which brings significant changes in various aspects of national life; therefore, it required continuous efforts to build and strengthen the identity of the Indonesian people. We can start by protecting and preserving the diversity of the traditional noble values and cultural heritage that still reflect Indonesian characteristics. The awareness of the world about the importance of preserving cultural heritage sites is increasing over time, providing an opportunity for the importance of implementing conservation to strengthen the resilience of Indonesian culture. One of the conservation efforts is to propose cultural heritage in the form of site, building complex, and cultural landscape that spread in the territory of Indonesia with their uniqueness as World Heritage that has universal values. World Heritage site is a national asset, so everyone has the right and obligation to understand, appreciate, and preserve the universal, national, and local values contained in it through an integrated and sustainable management mechanism. This study was the result of desk research with the analysis using a qualitative descriptive method based on literature studies from relevant references. The results of this study indicate that a positive approach in the management and utilization of the world heritage is by using a sustainable tourism approach through the cultural tourism concept. Here, tourism might be a tool to package the conservation efforts of the world heritage site to become a cultural tourist attraction. This study produced some recommendations that can apply to develop sustainable tourism in the World Heritage site.
\end{abstract}

Keywords: Cultural Heritage; World Heritage; preservation; sustainable tourism; cultural tourism

\section{INTRODUCTION}

The resilience of Indonesian culture today faces severe problems due to the influence of globalization that disregards the geopolitical boundaries of a country. Globalization also brings significant changes in various aspects of political, economic, social, and cultural life. This influence gradually hits Indonesia, and it is marked by the internalization of global ideas such as universalism, humanism, political ideology, economic system, and ecology, as the result of intercultural interactions. The external influence exacerbated by the emergence of various conflicts of interest, ideological differences, imbalances in economic exploitation, and degradation of identity and cultural understanding. Based on history, Indonesia's diversity is an essential gift. However, there is potential for conflict that is caused by differences in ethnicity, religion, race, class, and economic class background. To prevent conflict potential, unity between groups is needed to get past the divisions of the differences. (Simatupang, 2017: 209). Culture has become one of the elements used as a reference for the founder of the nation in designing diversity so that it merges into one called national culture, as revealed in Article 32 of the 1945 Constitution: 'National Culture' (Indonesia) is the cultural peaks in the region.

Today, culture is understood more as art, craft, and culinary. Even the history and culture widely exploited for economic interests into commodities, which slowly weakens the value system, belief system, thinking pattern, work pattern, and acting pattern as a reflection of the Indonesian cultural civilization identity. Continuous efforts to build and strengthen the nation's life, welfare, and identity of the Indonesian people need to be started by preserving the diversity of the noble values of tradition and cultural heritage that still reflect Indonesian culture. Indonesia has rich and invaluable diversity as well as unique cultural assets that are envied 
by the other nations in the world. One of them is cultural heritage in the form of a site, building complex to a cultural landscape that spread throughout the territory of Indonesia with their unique characteristics. In general, cultural researchers interpret cultural heritage 'formally,' which emphasizes more essential values in terms of science. Society certainly has its meaning that is more diverse and generally practical. As a result, the efforts to manage cultural heritage in Indonesia often characterized by conflicts of interest between the community and the government (Tanudirjo, 2003: 4).

The legal position governing the management of cultural heritage was formally established by the Indonesian government, in the form of Law No. 5 of 1992 on Heritage Objects, then updated in Law No. 11 of 2010 on Cultural Heritage (Mujabuddawat, 2015: 141). Cultural heritage is a local genius, which is the result of civilization manifestation and evidence of historical and cultural developments from the past that have a value forming the identity of political, economic, social, and national cultural life (Koentjaraningrat, 1990). Law Number 11 of 2010 states that objects, buildings, or structures that meet the criteria as Heritage Objects or Buildings are those that are more than 50 years old or represent the shortest period of 50 years (Law of the Republic of Indonesia, 2010). In carrying out the mandate of the Law, Lembaga Ilmu Pengetahuan Indonesia/LIPI (The Indonesian Institute of Sciences) has Community and Cultural Research Center, and Kementerian Pendidikan dan Kebudayaan/Kemdikbud (The Ministry of Education and Culture) also has Technical Implementation Unit spread throughout Indonesia that serves as a cultural research institute and technical executor in carrying out the conservation. The Technical Implementation Unit includes Pusat Penelitian Arkeologi Nasional/Puslit Arkenas (Archaeological Research Center) and Balai Pelestarian Nilai Budaya/BPNB (The Cultural Value Conservation Bureau) as a reference for Balai Pelestarian Cagar Budaya/BPCB (The Cultural Heritage Conservation Bureau) as a technical executor that plays a role in the conservation and implementation of the Cultural Heritage Law (Mujabuddawat, 2016: 31). Followed by the Ministry of Tourism (Kemenparekraf) who plays a role in organizing promotion and publication, as well as implementing policies in the tourism sector. Some Indonesian Cultural Heritages have designed as World Heritage recognized by UNESCO (2013), including the site area of Borobudur temple complex, Prambanan temple complex, Sangiran site area, and the cultural landscape in Bali related to Subak system.

A global view related to heritage studies in the world that also has been known and applied in Indonesia was written by Rodney Harrison. Surbakti (2017: 142-143), in his publication, he quotes Harrison (2013: 227) that heritage studies must address many things so that the
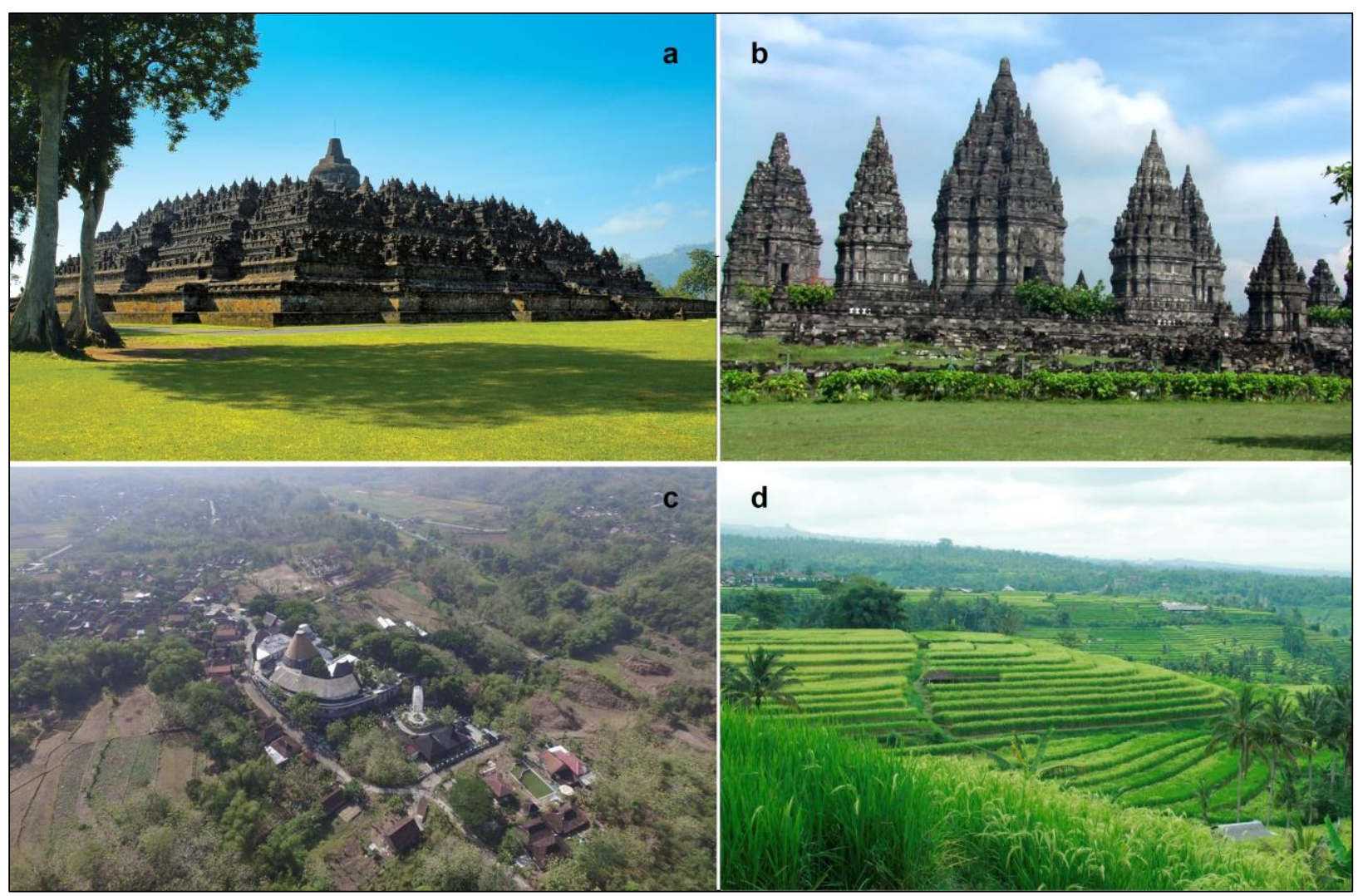

Figure 1. UNESCO World Heritage in Indonesia: a) Borobudur Temple; b) Prambanan Temple; c) Sangiran site area; d) Subak landscape

(source: KWRI UNESCO, date access November 16, 2018) 
involvement of public or broad audience can realize. The society must be accommodated in such a way with various circumstances and approaches, especially when looking at the current condition of contemporary global societies, which are so heterogeneous so that the dialogical concept between cultural preservation (materiality) and society now can be realized. Harrison (2013: 228) explains that the public has a responsibility to preserve cultural heritage. The concept of salvage and preservation is the basis of public involvement, which intersects with the heritage existing in the present. The communities may have an artefactual object or historical building due to inheritance, grant, or access that allows them to bound by the past. Awareness of the importance of managing and preserving cultural heritage is now increasing. Many of the lovers and observers of cultural heritage believe that cultural resources are not only inheritance but moreover a heritage for the Indonesian people, which means cultural resources have the power to use in helping and protecting this nation in treading the way to the future. As a heritage, the cultural heritage must be maintained so that it does not lose the power and can be passed on to future generations without diminishing its value (Surbakti, 2017: 143).

The value contained and the interests in cultural heritage cause various conflicts of interest. The conflict of interest and pluralism that develop in society also raises new discourses in the conservation vision. Many parties understand that preservation is an effort to direct the cultural heritage to 'not change' or 'restore it to its original state,' preservation carried out is only for the cultural heritage itself. This concept certainly cannot be applied to the old cultural heritage that has not been used by the community because it does not have a significant impact on the current system of society. Although several Cultural Heritages have the same characteristics as other cultural heritages such as non-renewable, finite, easily fragile, and contextual, it can be utilized in the present context with wise management. Preservation of heritage can apply by maintaining its value while actualizing it into the context of the current system of society (Astiti, 2017: 197-198).

Based on the background described, Cultural Heritage is a national asset. Everyone has the right and obligation to understand, appreciate, and preserve the universal, national, and local values contained in it through an integrated and sustainable management mechanism. With the establishment of World Heritage by UNESCO, it certainly brings pride to the nation, but behind that pride lies enormous challenges for the government in carrying out the conservation efforts by involving various stakeholders. Conservation efforts are carried out through various programs that can maintain the physical existence and value of the World Heritage. Not only for the sake of the government, more importantly, but also the conservation efforts must be able to provide new meaning and benefits to the world community, specifically the local community.

The problem discussed in this study is that although the World Heritage title was enthusiastically proposed by the government, the title has not provided benefits to the community. Many times the local communities feel that they get additional burden to keep providing the benefits to other parties such as the industry sector. Consequently, the daily life of the local community and the World Heritage site changes into a spectacle like a zoo. Based on this sad condition, it is necessary to change the way to manage cultural heritage in the future, which is currently very 'top-down.' One of the ways is management by using a sustainable tourism approach through the concept of cultural tourism as a conservation tool. Sustainable tourism products are products that are operated in harmony with the local environment, society and culture so that people continue to be beneficiary rather than the victim of tourism development (Astiti, 2016: 18). This study aims to discuss the sustainable tourism development that allows packaging of the preservation efforts of the World Heritage site to become a cultural tourist attraction.

\section{METHODS}

With its unrenewable nature, cultural heritage, including the World Heritage, is very vulnerable to the changes both caused by nature and humans. The condition of Indonesia, which has a humid tropical climate, is very influential in the process of physical change of cultural heritage from damage, weathering, and even destruction. Given the importance of World Heritage as national assets, conservation is significant in protecting the physical existence as well as the historical and cultural values contained in it. Sustainable tourism, through the concept of cultural tourism, can be used as a tool, concept, or approach in strengthening World Heritage conservation efforts. This study examined the main issues and opportunities for using World Heritage more deeply from the situation through the literature study and qualitative writing method. This study used a descriptive-analytical method with a qualitative approach. Qualitative method is a method for understanding the meaning of social or humanitarian problems in individuals or community groups (Chariri, 2009: 14; Creswell, 2016: 4; Creswell \& Miller, 2000). Qualitative research can provide an understanding of the phenomena studied through a holistic picture and multiplied deep understanding (Moleong, 2010: 31; Mansyur, 2010: 13). In this paper, desk research and data collection were conducted through a literature study by searching for relevant information from previous research (secondary sources) that can describe the observed variables while answering the problem. The 
sources of secondary data and information collected were obtained from scientific books, research reports, scientific journals, theses, dissertations, regulations, yearbook provisions, and other sources.

\section{RESUlt AND Discussion}

\section{Global Tourism Trends and Paradigms}

In the current globalization era, tourism has experienced changes in trend and paradigm, namely from tourist destinations that exploit resources massively that endanger the environmental sustainability; traveling for entertainment and satisfaction by gaining experience and knowledge; as well as man-made attractions to natural, unique, and authentic attractions (Cabrini, 2004: 1-10). These changes bring the current tourism (new tourism) as a field that can accelerate the development of developing countries. That is because it can help to create a balance of welfare, able to protect, develop and utilize natural and cultural resources wisely as an attraction; and able to give influence as well as contribution to the economy, social, education, culture and is expected to encourage the creation of friendship between nations through cultural diplomacy (Poon, 2003: 25-32). Tourism is:

$\checkmark$ Temporary human movement, interested in the unique nature of attractions that can only be obtained from the potential attraction of endemic and rare cultural and natural resources (Inskeep, 1991: 18-22).

$\checkmark$ Part of development that does not have to be seen as a modern economic machine that can erode the roots of traditional economic culture, but instead to development that can foster creativity, strengthen environmental conservation and cultural preservation, enhance intercultural relation, and improve welfare through conservation the cultural roots of society.

$\checkmark$ An economical process of experience that contains conservative but not exploitative spirit by preventing natural exploitation and mass modification in an unsustainable manner.

$\checkmark$ Activity that grows naturally based on the community, from the community to the community.

$\checkmark$ Not the ultimate goal, but as a development tool that can foster creativity, strengthen insights into environmental conservation and cultural preservation, improve understanding of intercultural relations, and improve welfare through the preservation of the cultural roots of society.

\section{Approach \\ Sustainable Tourism}

In general, sustainable development terminology guarantees the preservation of the natural and cultural environment by actively involving the community, so that it can economically improve the various parties involved and the quality of the environment and local communities (Cooper, Fletcher, Gilbert, \& Wanhill, 1996: 21-23). Sustainable tourism with the environment, empowerment, and economic pillars of the community have been proven when positioned as one of the development tools. Able to provide benefits including increasing efforts to preserve environmental resources, both natural attraction and cultural appeal, fostering economic activities that can increase employment and business opportunities, and strengthening the role and involvement of the community in development based on

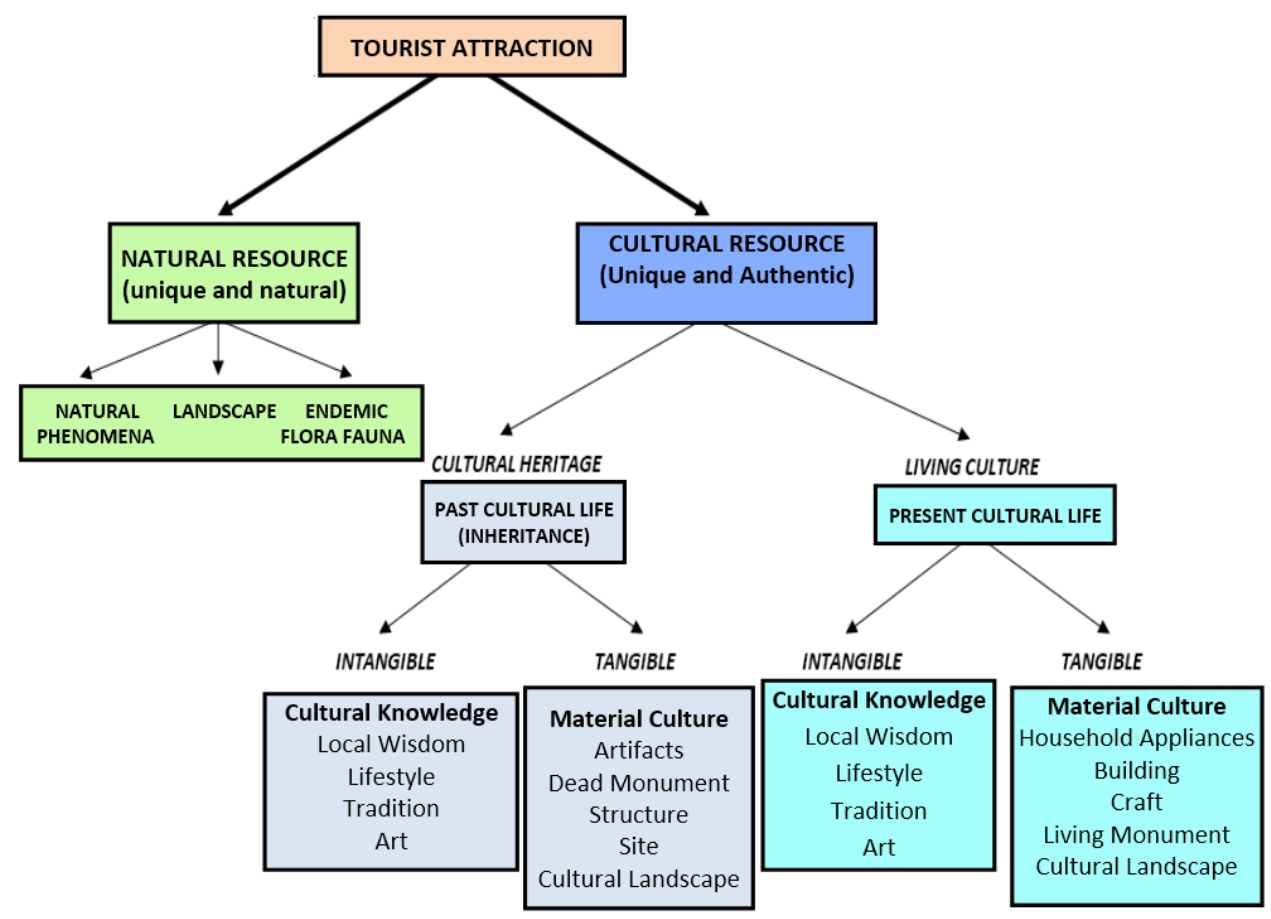

Figure 2. Tourism Attraction Resources (source: Author, 2017) 
the resilience of cultural roots as identity. The diversity of tourism attractions can be grouped based on the primary attraction sources, as shown in the Figure 2.

Referring to sustainable tourism as a global policy, and according to Law No. 10 of 2009, Indonesia places tourism as an integral part of national development. This effort is carried out by stakeholders in an integrated manner to build tourism based on religious norms, preservation of natural resources, culture and its environment, and pay attention to the interests of ideological, political, economic, social and cultural (Ipoleksosbud), and national defense and security (Hankamnas).

\section{Cultural Tourism}

The implementation of tourism by utilizing the cultural attraction has carried out, so that the tourists obtain something new, unique, more knowledge, and get to know intimately about the diversity of Indonesian culture. Figure 2 shows that the source of cultural attraction can be divided into the cultural heritage that is already unused or not functioning, and the present cultural life that is still carried out or functioning. Each of them has elements as proof of its existence, which is tangible and intangible. Those elements in tourism become an attraction, in which, when packaged through activities and interpretations (storytelling), can provide satisfaction to the experience and knowledge desired by the tourists.

In its implementation, it still focuses on the utilization of the physical attraction of cultural heritage as an economic commodity, so it has not yet reached a full understanding of about economization of experience and knowledge. As a result, it causes polemic between culture as a heritage and culture as capital. Conceptually, cultural tourism is: $\checkmark$ A concept of developing cultural resources-based tourism that aims to support the preservation of culture and environment by increasing community participation in the sustainable use of cultural resources as a tourist attraction.

$\checkmark$ A tourism activity based on cultural notions as past community wealth depicted through monuments, historical sites, architecture, or artifacts (Shilling, 2000: 5-9).

$\checkmark$ A journey to develop an appreciation and increase knowledge of cultural heritage related to sociocultural life aspects such as history, tradition, customs, language, and so on (Fletcher, 1997: 140146).

$\checkmark$ An activity related to human work that is beautiful or limited to art (creative art) such as theater, dance, opera, and painting (Csapó, 2012: 202-203).

$\checkmark$ A type of tourism based on the attraction of conservation efforts (protection, utilization, and development) of cultural heritage, which includes areas of the cultural heritage site, tradition, art, ceremony, and livelihood (FAD, 1999: 15-29).

\section{Condition}

Tourism in Indonesia has developed. Tourism positioned as the ultimate goal in increasing economic development, which has an impact on various exploitative activities to the attractiveness of natural and cultural resources that are full of economic values. In practice, tourism has deviated into productionconsumption-distribution activities in which the purpose is more on the profit, not on the principle of sustainability based on scarcity (Gunn, 1980: 8-10). Tourism development has forgotten the human element and its environment as a central variable in industrial design. As a result, when tourism involves cultural resources,

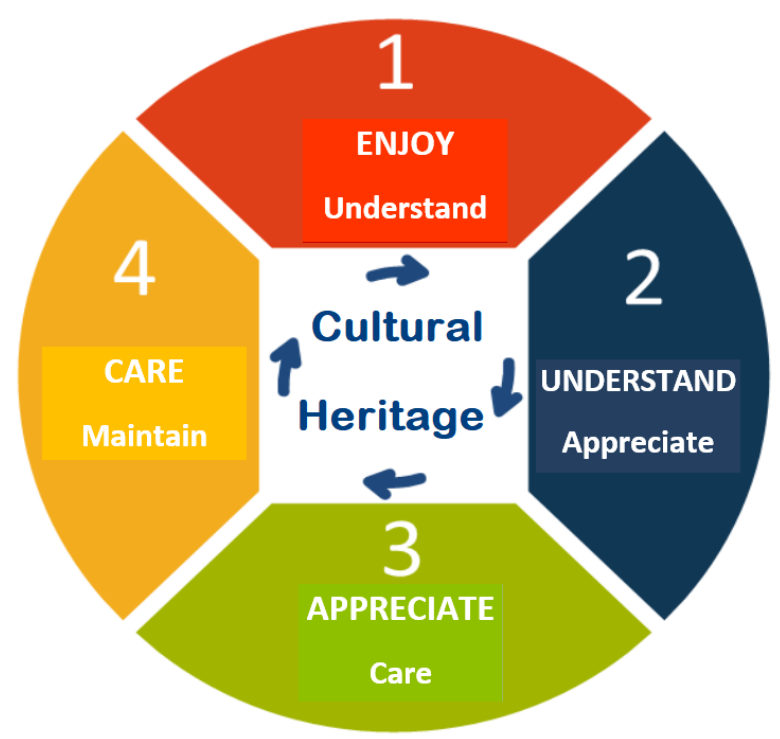

Figure 3. Cultural Heritage Attraction Management Cycle (Source: CiD, 2013) 
including the World Heritage with such economic understanding, conflicts occur with the values contained in the culture. This condition ultimately gave birth to a polemic between World Heritage as a heritage which is more oriented towards conservation (Maintaining and Developing), with World Heritage as capital that is more oriented towards utilization (Empowering and Capitalizing) and nurturing commodification of cultural elements in World Heritage (Pedersen, 2002: 30-35), though both should complement each other, not dominate or negate each other.

Conservation without utilization is impossible because preservation certainly requires capital. Conversely, utilization without conservation is also impossible because utilization requires resources that have value. According to Swarbrooke (2002: 40-46), a relationship that complements each other can guarantee the sustainability of both culture and tourism with the Sustainable Tourism Approach through the concept of Cultural Tourism. Cultural tourism for Indonesia should be capable as a tool to build an integrated effort to manage the World Heritage resources sustainably. Particularly with the shift of global trends and paradigms, the preservation of World Heritage through cultural tourism is a significant factor in paying attention to various aspects related to the environment, social, culture and economy, and to prioritize local community empowerment.

\section{World Heritage Development Strategy as a Tourist Attraction}

Culture, including World Heritage, will be inherited from one generation to the next in the local community. As a property and included in the cultural system of society, tourism should be managed from, by, and for the community. Therefore, the developed tourism strategy form should be based not only on the physical attractiveness of the World Heritage site, but it also must be directed at the preservation of World Heritage sites as a tourist attraction. Several things need to consider in developing cultural tourism in the World Heritage site, including:

\section{Direction}

The management of World Heritage sites, according to Ardiwidjaja (2013: 20-24), is a form of an effort to preserve the existence of historical, cultural, and physical values to attract cultural tourism destinations while simultaneously providing benefits to the community. Therefore the development of tourism in the World Heritage site must be:

$\checkmark$ Socially accepted. The development carried out can provide an opportunity to improve the quality of the socio-cultural life of the local community. $\checkmark$ Culturally appropriate. The development carried out must also refer to the norms and values that apply to the cultural roots of the local community.

$\checkmark$ Environmentally sound. The development carried out must be positioned as a management tool that can adapt to the conditions of the natural environment and cultural roots in an integrated and sustainable manner.

$\checkmark$ People-centered. The development carried out must be oriented to the involvement of local communities' role as beneficiaries.

$\checkmark$ Indiscriminative. The development carried out must grow from, by, and for the welfare of society, by prioritizing balance, equity, and equality.

\section{Principle}

The application of cultural tourism in the World Heritage site area must be able to accommodate various long-term interests that pay attention to the strategic value of various site aspects, including:

$\checkmark$ Environmental aspects. The environment is essential in managing the World Heritage site area through a carrying capacity approach so that spatial and time contextual relationship from historical and cultural values on the World Heritage site with the surrounding environment is maintained.

$\checkmark$ Social and cultural aspects. The World Heritage site is the result of past creativity that is applied in the form of objects, containing cultural knowledge values that are passed down from generation to generation to the supporting community, which may still influence and reflect in the socio-cultural life of the local community until now.

$\checkmark$ Education and science aspects. The World Heritage site area created to have purpose and objective based on the cultural knowledge of the creator. In other words, the World Heritage site is a capsule containing scientific values that reflect the level of civilization in the past.

$\checkmark$ Economic aspects. In addition to the value of science, the World Heritage site also has economic values if managed by using cultural tourism as a means of cultural tourism attraction based on education and preservation, as well as a tool to stimulate employment and business opportunities based on the cultural roots of daily life.

$\checkmark$ Recreational aspects. The World Heritage site area is proof of past civilization that contains the uniqueness of historical and cultural values. The value and uniqueness create an attraction that motivates people to visit to gain experience and knowledge as well as recreation.

$\checkmark$ The aesthetic aspect of the natural environment World Heritage that comes from the cultural knowledge of the society in the past was created to 
meet the needs of life and adapt to the situation and condition of the surrounding environment, including from the aesthetic aspects of that period.

$\checkmark$ Ideology aspects. The World Heritage area as a proof that contains view or understanding of the philosophy of Indonesian civilization in the past has an identity value that allows for inspiring the past through the present pattern for the resilience of Indonesian culture in the future.

\section{Delineation}

One of the essential principles in developing the World Heritage site area into a sustainable tourism destination that often overlooked is delineation. In principle, delineation of cultural heritage areas including World Heritage in sustainable tourism determines the boundaries of the region's carrying capacity to enforce conservation from the protection, development, up to utilization of existing potential from the increase of tourist numbers to the types of tourism product and activity (Coccossis, Mexa, Collovini, Parpairis, \& Konstandoglou, 2001: 10-14). Many cases of tourism development have failed to protect, develop, and utilize the existence of value and physical of World Heritage sites on an ongoing basis.

Failures frequently occur and cause the extinction of the World Heritage site on the order of ecosystem, economy, and local socio-cultural life. Generally, it occurs because people do not refer to the holistic analysis of existing potential spatial diversity from delineation results. Therefore the delineation in the World Heritage site area is essential not only for protecting its existence as an asset of the nation and the world but also for developers to utilize the values contained, including scientific values to economic values for the society, especially the local community.

\section{Interpretation}

Cultural heritage as a heritage or legacy from the past is a source of life and irreplaceable inspiration that needs to preserve. The word 'heritage' as a synonym for objects from the past, applied in various contexts that have associations with events and non-physical aspects of the past, such as artistic and cultural works (Rodney Harrison, 2010: 9-14). Likewise, World Heritage, which contains historical values and national culture, is proof of the past that should be interpreted correctly in the present life for the benefit of future generations. Therefore, communicating the meaning of the values contained behind the World Heritage through interpretation (storytelling) for the community in the present and future becomes essential. Interpretation can provide an overview not only in reconstructing the history and cultural knowledge of the past, but also in providing further perception, understanding, and interest from the community including tourists to be focused (Mossberg, Therkelsen, Huijbens, Björk, \& Olsson, 2010: 4-7). Unfortunately, this process is often forgotten or not implemented optimally in every World Heritage conservation effort, both tangible and intangible.

For sustainable tourism, a proper interpretation of the form, type, and value contained in the World Heritage site is the charm for tourists to visit while being able to give satisfaction to the community and tourists in a flow of past experiences based on current knowledge. According to Moscardo, (2003: 112-121), the interpretation of experts, namely archeologists, anthropologists, and historians in interpreting the value of the World Heritage site is one of the keys to the success of preservation-based sustainable tourism in the World Heritage site because:

$\checkmark$ It develops the understanding and knowledge of stakeholders, they work together to protect and maintain, while using the World Heritage and its natural environment wisely.

$\checkmark \quad$ It increases awareness and appreciation of the tourists and local community in particular about the importance of World Heritage, for example, the value of local wisdom, traditions, beliefs, customs, and history of local communities to be preserved.

$\checkmark$ It changes the behavioral patterns of visitors and local communities that can have an impact on the existence and environmental sustainability of the World Heritage site.

$\checkmark$ It invites the community, community institutions, tourists, and other interested parties to support the preservation of World Heritage sites and their environment as a sensitive area and cultural tourism destination.

\section{Involvement}

According to Law Number 11 of 2010 on Cultural Heritage, cultural heritage include the World Heritage areas necessarily to be managed by the government and regional government by increasing the participation of the community to protect, develop and utilize cultural heritage. However, the role of stakeholders and the local community in managing the site area is still minimal. The local community, along with other parties who have an interest in the site area feel that the management carried out by the government narrows the space and alienates the relationship between the community and the World Heritage site. The result is creating various kinds of conflicts of interest ranging from conflicts of ownership to authority (Smith \& Robinson, 2006: 89-99).

Basically, for many parties, the World Heritage site has an essential meaning as needed, and it depends on the perspective of how to see the potential existing on the site. According to Pedersen (2002: 38-40), in solving the problems of interests that hinder conservation efforts in 
the site area, sustainable tourism can be an alternative means of opening up access for stakeholders to be involved and play an active role through community empowerment activities in tourism (community-based tourism). The activity will map the roles and functions of (who does what) each party involvement that includes:

$\checkmark$ Governing Bodies are international and national level bodies that have the authority to make and enforce policies and regulations relating to management such as the World Tourism Organization (WTO), World Heritage Center, UNESCO, DPR/DPRD, and related local governments.

$\checkmark$ Developers are those who drive the tourism economy, which consist of travel agents, tour operators, tour guides, providers of accommodation and restaurant facilities, managers of Cultural Tourism attraction, and others.

$\checkmark$ Conservation Community are agencies, institutions or groups that place cultural and environmental preservation in a sustainable framework as the focus of their work such as World Wild Fund (WWF), Wahana Lingkungan Hidup/WALHI (Living Environment Facility), The Nature Conservancy (TNC), International Council on Monument and Sites (ICOMOS), International Music Council (IMC), Ikatan Ahli Arkeologi indonesia/IAAI (The Indonesian Archaeologist Association), Badan Penelitian dan Pengembangan Industri/BPPI (Industrial Research and Development Agency), and others.

$\checkmark$ Hosting Communities are societies that have the origin of authentic local elements in an area that has cultural tourism attractions around the World Heritage location. Local people have an interest in maintaining their identity, authenticity, value system, and welfare, such as indigenous peoples, religious communities, craftsman communities, traditional artist communities, and others.

$\checkmark$ Funding Agencies are philanthropic bodies that provide financial assistance and facilities in the form of grants to various parties who make conservation efforts such as Rockefeller Foundation, Ford Foundation, Open Society, Asia Foundation, and others.

$\checkmark$ Tourist is someone or a group of people who make a trip somewhere outside the routine and not to get a salary. Tourist interests differ from one another so that they form several segments in the world tourism market.

\section{Conclusion}

Today and in the future, tourism should no longer use culture as a commodity. However, culture is the one that utilizes sustainable tourism as a tool to strengthen conservation efforts. As a foundation for the development of sustainable tourism in the World Heritage site area, it is necessary to pay attention to several issues that influence it, namely the perspective of development in all sectors must be based on a sustainable order, including the tourism sector. Sustainable tourism also called 'Smart Tourism' because it based on aspects of natural and cultural environment conservation, improving the quality of the community's life and economic empowerment of the local community. Some understanding of cultural tourism from experts related to cultural tourism activities of the people described through cultural heritage in the form of monuments, archaeological sites, and historical sites. Then the understanding related to a journey to increase appreciation and knowledge of cultural heritage, as well as understanding that related to the aspects of sociocultural life such as history, tradition, custom, language, and others.

For Indonesia, based on the developed countries' experience and the diversity of cultures they have, cultural tourism is more appropriate if it categorized as a foundation that covers various forms of tourism activities both related to heritage culture, as well as those related to the heritage itself. However, both of them still emphasize the cultural components, both tangible and intangible. In the management of the World Heritage site area through a sustainable tourism approach that oriented to the concept of cultural tourism, conservation efforts must be seen as educational-based tourist attractions. Some recommendations that can convey in developing sustainable tourism in the World Heritage site include:

1. The strategy for understanding the tourism actors towards tourist satisfaction with authentic World Heritage experiences as a manifestation of life and human identity, as a process of cultural interaction and its impact, and as an attraction for tourist consumption.

2. Tourist market strategy that focuses on specific interest tourists, tourists who want to interact with local communities, and tourists who care about conservation and conservation efforts.

3. The economic strategy that emphasizes the quality of tourist satisfaction moreover, it will determine the amount of income by considering the local community in providing quality products, services, which also must be able to control tourists in terms of length of stay, expenditure, and interest in shopping, as well as the choice of tourist market share desired.

4. Strategies for implementing cultural tourism that is formulated and mutually agreed upon by the actors by taking into account the aspects of community involvement, environmental interpretation education, and carrying capacity of the social and cultural environment to negative impacts that are related to 
the types of attraction and attraction, ownership, and facilities up to visitor management.

5. Monitoring strategy for the implementation of cultural tourism by involving all parties and still referring to the sustainable principles with measurements that refer to the sustainability indicators of the World Heritage site, strengthening cultural roots, and improving the economy of the community.

\section{ACKNOWLEDGEMENT}

I would like to express gratitude to all parties who helped compile this small study until it becomes a scientific article and Kapata Arkeologi that allow publishing this article. Hopefully, it will be useful for science.

\section{REFERENCES}

Ardiwidjaja, R. (2013). Pariwisata Berkelanjutan: Pengembangan Destinasi Pariwisata Berbasis Lingkungan. Yogyakarta: Penerbit Kepel Press.

Astiti, N. K. A. (2016). Sumber Daya Arkeologi dalam Pembangunan Pariwisata Berkelanjutan di Provinsi Maluku. Kapata Arkeologi, 12(1), 15-28.

Astiti, N. K. A. (2017). Kawasan Kompleks Bangunan Megalitik di Kabupaten Lahat sebagai Daya Tarik Wisata Budaya dan Alam. Kapata Arkeologi, 13(2), 195-208.

Cabrini, L. (2004). Trend of International Tourism. In 13th Central European Trade Fair. New York: World Trade Center.

Chariri, A. (2009). Landasan Filsafat dan Metode Penelitian Kualitatif. In Metodologi Penelitian Kuantitatif dan Kualitatif (pp. 1-27). Semarang: Fakultas Ekonomi Universitas Diponegoro Semarang.

CiD. (2013). What is Cultural Heritage. Retrieved from http://www.cultureindevelopment.nl/

Coccossis, H., Mexa, A., Collovini, A., Parpairis, A., \& Konstandoglou, M. (2001). Defining, Measuring and Evaluating Carrying Capacity in European Tourism Destinations. Athens: Environmental Planning Laboratory.

Cooper, C., Fletcher, J., Gilbert, D., \& Wanhill, S. (1996). Tourism Principles and Practice. Malaysia: Longman Group Limited.

Creswell, J. W. (2016). Research Design: Pendekatan Metode Kualitatif, Kuantitatif, dan Campuran. Yogyakarta: Pustaka Pelajar.

Creswell, J. W., \& Miller, D. L. (2010). Determining Validity in Qualitative Inquiry. Theory Into Practice, 39(3), 124130.

Csapó, J. (2012). The Role and Importance of Cultural Tourism in Modern Tourism Industry. In M. Kasimoglu (Ed.),

Strategies for Tourism Industry - Micro and Macro Perspectives (pp. 201-232). London: InTech.

FAD. (1999). Cultural System: For Quality Management, Bangkok, Thailand. Bangkok: The Fine Art Department (FAD) of Thailand.

Fletcher, J. (1997). Heritage Tourism: enhancing the net benefits of tourism. In Tourism and Heritage Management (pp. 134-146). Yogyakarta: Gadjah Mada University Press.

Gunn, C. A. (1980). Tourism Planning. New York: Crane Russak \& Company, Inc.

Harrison, R. (Ed.). (2010). Understanding the Politics of Heritage. Manchester: Manchester University Press in association with the Open University, Manchester and Milton Keynes.

Harrison, R. (2013). Heritage Critical Approaches. London: Routledge.

Inskeep, E. (1991). Tourism Planning. An Integrated and Sustainable Development Approach. New York: Van Nostrand Reinhold.

Koentjaraningrat. (1990). Pengantar Ilmu Antropologi. Jakarta: Rineka Cipta.

KWRI UNESCO. Data dan Publikasi. Retrieved November 16, 2018, from http://kwriu.kemdikbud.go.id/

Mansyur, S. (2010). Konstruksi Baru Pameran Museum Kota Makassar. Post Graduate Thesis: Universitas Indonesia.

Moleong, L. J. (2010). Metodologi Penelitian Kualitatif (ed. Revisi). Bandung: Remaja Rosdakarya.

Moscardo, G. (2003). Interpretation and Sustainable Tourism: functions, examples and principles. [Reprint of original article published in v. 9, no. 1, 1998: 2-13.]. Journal of Tourism Studies, 14(1), 112-123.

Mossberg, L., Therkelsen, A., Huijbens, E. H., Björk, P., \& Olsson, A. K. (2010). Storytelling and Destination Development: Nordic Innovation Centre. Copenhagen: Nordic Council of Ministers.

Mujabuddawat, M. Al. (2015). Kompleks Situs Ki Buyut Trusmi Cirebon: Tinjauan Bangunan Kuna. Kapata Arkeologi, 11(2), 139-154.

Mujabuddawat, M. Al. (2016). Perangkat Sistem Informasi Geografis (SIG) dalam Penelitian dan Penyajian Informasi Arkeologi. Kapata Arkeologi, 12(1), 29-42.

Pedersen, A. (Ed.). (2002). Managing Tourism at World Heritage Sites: a Practical Manual for World Heritage Site Managers. In World Heritage Paper 1. Paris: UNESCO World Heritage Centre.

Poon, A. (2003). A New Tourism Scenario-Key Future Trends. In The Berlin Report, Tourism Intellegence International. Berlin.

Shilling, D. (2000). Cultural Heritage Tourism: Practical Application. Phoenix, Arizona: Arizona Humanities Council.

Simatupang, D. E. (2017). Revitalisasi Kebinekaan melalui Kampanye Slogan Arkeologis Hasil Penelitian Situs Kota Cina. Kapata Arkeologi, 13(2), 209.

Smith, M., \& Robinson, M. (2006). Cultural Tourism in a Changing World: Politics, Participation and (Re)presentation. Clevedon: Channel View Publications.

Surbakti, K. (2017). Kebijakan Pengelolaan Warisan Budaya Ditinjau dari Undang-Undang Nomor 11 Tahun 2010 (Perihal Pemberian Insentif dan Kompensasi). Kapata Arkeologi, 13(2), 141-150.

Swarbrooke, J. (2002). Development \& Management of Visitor Attraction. Oxford: Butterworth-Heinemann.

Tanudirjo, D. A. (2003). Warisan Budaya untuk Semua, Arah Kebijakan Pengelolaan Warisan Budaya Indonesia di Masa Mendatang. In Makalah Kongres Kebudayaan V (pp. 19-23). Bukit Tinggi: Kongres Kebudayaan Indonesia. 
Undang-undang RI. UU tentang Cagar Budaya, Pub. L. No. 11 (2010). Indonesia.

UNESCO. (2013). Managing Cultural World Heritage. In G. Wijesuriya, J. Thompson, \& C. Young (Eds.), World Heritage Resource Manual 16/11/2013. Paris: UNESCO. 